\title{
ANALISIS PENGGUNAAN FAKTOR PRODUKSI \\ PADA PERUSAHAAN AYAM RAS PETELUR \\ (STUDI KASUS PADA UD. KAKASKASEN INDAH \\ DAN CV. NAWANUA FARM)
}

Chintia C. L. Salele; Boyke Roimpandey*; Masje T. Massie*; Poulla O. V. Waleleng*

Fakultas Peternakan Universitas Sam Ratulangi Manado, 95115

\begin{abstract}
ABSTRAK
Usaha peternakan ayam ras petelur merupakan salah satu ternak unggas yang dapat mendukung program pemerintah, karena keunggulannya dalam memproduksi telur. Permasalahannya berapa besar tingkat keuntungan dalam satu periode produksi dan sampai skala produksi berapa perusahaan ayam ras petelur pada UD. Kakaskasen Indah dan CV. Nawanua Farm mencapai Break Even Point belum diketahui. Penelitian ini bertujuan untuk mengetahui besar penggunaan faktor produksi, tingkat keuntungan dan titik impas dari perusahaan ayam ras petelur di kota Tomohon. Penelitian dilaksanakan dengan menggunakan metode survey. Pengambilan data dilakukan dengan observasi lapangan dan wawancara langsung terhadap pemilik perusahaan ayam ras petelur yakni perusahaan CV. Kawanua Farm dan UD. Kakaskasen Indah. Hasil penelitian pada kedua perusahaan ayam ras petelur menunjukkan bahwa biaya terbesar dari keseluruhan biaya produksi ialah biaya pakan sebesar $69,44 \%$ untuk perusahaan CV. Nawanua Farm dan 76,66\% untuk perusahaan UD. Hasil analisis diperoleh tingkat keuntungan pada perusahaan Nawanua Farm sebesar Rp 5.247.257.316 per periode produksi dengan skala usaha sebesar 21.000 ekor per periode produksi, BEP Rp. 209.297.896 untuk 10.956 ekor, MOS 94,36\% dan ROI 1,78. Tingkat keuntungan pada perusahaan Kakaskasen Indah sebesar Rp 17.523.288.446 per periode produksi dengan skala usaha sebesar 60.000 ekor per periode produksi, BEP Rp 517.417.088 untuk 24.851 ekor, MOS 96,38\% dan ROI 1,25. Hasil analisis menunjukkan bahwa kedua perusahaan sudah menggunakan modal secara efisien dibuktikan oleh nilai MOS dan ROI yang memberikan tingkat keuntungan dan sudah beroperasi diatas titik impas.
\end{abstract}

Kata kunci : Faktor Produksi, BEP, MOS, ROI

\section{ABSTRACT}

\section{ANALYSIS OF PRODUCTION FACTOR UTILIZATION AT LAYING HEN FARMS (CASE STUDIES AT UD. KAKASKASEN INDAH AND CV.} NAWANUA FARM). Laying hen farm can support the government program due to its prominence in egg productivity. The problem that must be evaluated were how much the profit in one period of production gained and how many the scale of laying hen farm to reach the break event point. The laying hen farms used in this study were UD. Kakaskasen Indah and CV. Kawanua Farm. The objectives of this study were to evaluate utilization of production factor, profit level and break event point. Research was conducted by survey method. Data were collected based on field observation and

*Alumni Fakultas Peternakan

**Jurusan Sosial Ekonomi 
direct discussion with the owners of laying hen farms. Results showed that both laying hen farms had the largest production costs of $69.44 \%$ for animal feeding on CV. Kawanua Farm and $76.66 \%$ for animal feeding on UD. Kakaskasen Indah. Analysis of profit level on CV. Kawanua Farm were Rp. 5,247,257,316 per production period with farm scale of 21,000 heads of animals per production period. The BEP were Rp. 209,297,896 for 10,956 heads of animals, with MOS of $94.36 \%$ and ROI of 1.78 . Analysis of profit level on UD. Kakaskasen Indah were Rp. 17,523,288,446 per production period with farm scale of 60,000 heads of animals per production period. The BEP were Rp. 517,417,088 for 24,851 heads of animals, with MOS of $96.38 \%$ and ROI of 1.25. Results of analysis showed that both laying hen farms were using the capital efficiently as indicated by profitable values of MOS and ROI above the break event point.

\section{Kata kunci : Production factor, BEP, MOS, ROI}

\section{PENDAHULUAN}

Usaha peternakan ayam ras petelur merupakan salah satu ternak unggas yang dapat mendukung program pemerintah, karena keunggulannya dalam memproduksi telur. Berkembangnya usaha peternakan ayam ras petelur dapat memberikan sumbangan dalam pemenuhan gizi dengan harga yang terjangkau pada kalangan masyarakat. Usaha ini mampu menyediakan lapangan kerja tidak hanya terbatas di pedesaan tetapi juga di perkotaan. Selain itu, usaha ini mempunyai posisi strategis dalam meningkatkan kualitas sumberdaya manusia melalui penyediaan protein hewani.

Usaha peternakan ayam ras petelur di Kota Tomohon terus mengalami peningkatan yaitu tahun 2010 berjumlah 327.800 ekor, tahun 2011 sebanyak 360.500 ekor dan tahun 2012 berjumlah 378.525 ekor (Dinas Pertanaian dan Peternakan Sulut, 2012). Produktivitas peternakan ayam ras petelur dipengaruhi oleh berbagai faktor yang bersifat internal maupun eksternal. Faktor internal antara lain faktor teknis yang meliputi pemuliabiakan, pemberian jumlah dan mutu pakan, manajemen (tenaga kerja), dan pencegahan penyakit. Faktor eksternal meliputi faktor sosial ekonomi, kebijakan dan peraturan, serta kondisi alam lingkungan tempat berusaha. Selain faktor di atas, keberhasilan usaha peternakan juga dipengaruhi oleh kemampuan petani peternak dalam mengembangkan modal yang tujuannya memperoleh keuntungan yang dapat dipertahankan bahkan ditingkatkan hingga tahun-tahun mendatang.

Kota Tomohon terdapat beberapa kecamatan yang bergerak pada usaha peternakan ayam ras petelur, antara lain Kecamatan Tomohon Utara khususnya di Kelurahan Kakaskasen Dua dan Kakaskasen Tiga yaitu terdapat perusahaan ayam ras petelur UD. Kakaskasen Indah dan CV. Nawanua Farm. Perusahaan CV. Nawanua 
Farm merupakan perusahaan warisan keluarga yang didirikan pada tahun 1987 dengan populasi awal ternak ayam ras petelur sebanyak 1000 ekor. Tahun 2013 perusahaan tersebut memiliki populasi ternak ayam ras petelur sebanyak 21.000 ekor dan memiliki luas lahan sebesar 2 hektar. Sedangkan perusahaan UD. Kakaskasen Indah merupakan perusahaan milik sendiri yang didirikan pada tahun 1986 dengan populasi awal ternak ayam ras petelur sebanyak 1500 ekor. Tahun 2013 memiliki populasi ternak ayam ras petelur sebanyak 60.000 ekor dan memiliki luas lahan sebesar 4 hektar. Harga bibit ayam ras petelur (DOC) yang dibeli baik UD. Kakaskasen Indah dan CV. Nawanua Farm rata-rata Rp 5.500/ekor. Perusahaan UD. Kakaskasen Indah dan CV. Nawanua Farm memperoleh bibit ayam dari Surabaya.

Pengelolaan suatu usaha peternakan ayam ras petelur sangat penting memperhitungkan aspek-aspek korbanan dalam mencapai suatu tujuan perusahaan seperti memperoleh tingkat keuntungan yang layak. Setiap peternak dalam pengambilan keputusan pada suatu proses produksi harus memperhitungkan besarnya korbanan, mengingat setiap korbanan yang dilakukan untuk usaha produktif selalu memperhitungkan berapa besar keuntungan yang akan diperoleh.

Kondisi perekonomian saat ini, banyak dipengaruhi oleh berbagai aspek sosial ekonomi antara lain adanya kenaikan tarif bahan bakar minyak yang mengakibatkan meningkatnya harga-harga input. Harga input pada suatu usaha peternakan ayam ras petelur akan memberikan pengaruh dalam proses produksi sehingga diperlukan suatu perhitungan input output, mengingat usaha peternakan ayam ras petelur semakin berkembang, baik dalam skala usaha kecil maupun skala yang lebih besar. Hal ini disebabkan karena ternak ayam ras petelur mampu berproduksi 200 - 250 butir/ tahun/ekor dan ayam ras petelur yang sudah afkir (tidak produktif) mudah dipasarkan sebagai sumber daging asal ternak.

Berdasarkan pemikiran di atas, besar kecilnya keuntungan dalam usaha peternakan ayam ras petelur ditentukan oleh besarnya harga input dan harga output pada suatu proses produksi. Permasalahannya berapa besar tingkat keuntungan dalam satu periode produksi perusahaan ayam ras petelur dan sampai skala produksi berapa perusahaan ayam ras petelur pada UD. Kakaskasen Indah dan CV. Nawanua Farm mencapai Break Even Point belum diketahui. Berdasarkan permasalahan tersebut maka tujuan penelitian ini adalah (1) menganalisis tingkat keuntungan perusahaan ayam ras petelur pada UD. Kakaskasen Indah dan CV. Nawanua Farm dalam satu periode 
produksi; dan (2) menganalisis skala produksi berapa perusahaan ayam ras petelur pada UD. Kakaskasen Indah dan CV. Nawanua Farm mencapai Break Even Point.

\section{MATERI DAN METODE PENELITIAN}

Penelitian ini dilaksanakan pada perusahan ayam ras petelur yakni CV. Nawanua Farm dan UD. Kakaskasen Indah Kelurahan Kakaskasen Dua dan Kakaskasen Tiga Kecamatan Tomohon Utara Kota Tomohon sejak tanggal 19 Januari sampai 23 Februari 2014. Data yang dikumpulkan meliputi data primer yaitu data sekunder. Data primer diperoleh dengan wawancara langsung dengan peternak sebagai responden di lokasi peternakan yang berpedoman pada daftar pertanyaan. Data sekunder yaitu data yang diperoleh dari situs-situs internet, studi pustaka, laporan-laporan dari instansi yang berhubungan dengan penelitian. Metode penentuan sampel dilakukan dengan menggunakan pendekatan studi kasus pada perusahaan peternakan ayam ras petelur CV. Nawanua Farm dan UD. Kakaskasen Indah Kelurahan Kakaskasen Dua dan Kakaskasen Tiga. Instrumen pengumpulan data menggunakan daftar pertanyaan yang sudah disiapkan. Studi kasus merupakan pengujian secara rinci terhadap satu latar atau satu subjek atau satu tempat atau satu peristiwa tertentu (http://alfahchintya23.wordpress.com/2008/02/23/metode-penelitian-studi-kasus/).

Data yang dikumpulkan ditabulasi dan dianalisis dengan menggunakan pendekatan model analisis deskriptif dan matematik. Pendekatan analisis deskriptif dimaksudkan untuk menguraikan data kualitatif yang diformulasikan dalam bentuk tabelaris ataupun persentase. Pendekatan model analisis matematik dimaksudkan untuk menganalisis alokasi biaya produksi dan tingkat keuntungan (profit) pada perusahaan ayam ras petelur CV. Nawanua Farm dan perusahaan ayam ras petelur UD. Kakaskasen Indah melalui model analisis keuntungan (profit), Return Of Invesment (ROI) dan Break Even Point (BEP) serta Margin Of Safety (MOS).

\section{HASIL DAN PEMBAHASAN}

Usaha peternakan ayam ras petelur di Kota Tomohon merupakan salah satu usaha yang diusahakan oleh masyarakat dan telah mengalami perkembangan yang cukup pesat. Perkembangan tersebut di topang dengan adanya keadaan iklim yang sejuk yaitu keadaan suhu $18^{\circ} \mathrm{C}-30^{\circ} \mathrm{C}$. Keadaan tersebut memungkinkan ternak ayam ras 
petelur untuk dikembangkan. Menurut Rasyaf (2001) bahwa, ternak ayam ras petelur dapat beradaptasi dan dikembangkan secara optimal pada temperatur $18^{0} \mathrm{C}-21^{0} \mathrm{C}$.

Perusahaan peternakan ayam ras petelur yang dijadikan sampel dalam penelitian ini yaitu perusahaan peternakan ayam ras petelur UD. Kakaskasen Indah dan perusahaan peternakan ayam ras petelur CV. Nawanua Farm. Adapun karakteristik perusahaan peternakan ayam ras petelur masing-masing yang dijadikan sampel penelitian dapat dilihat dari Tabel 1.

Tabel 1. Karakteristik Perusahaan Peternakan Ayam Ras Petelur

\begin{tabular}{|c|c|c|c|}
\hline \multirow{2}{*}{ No. } & \multirow{2}{*}{ Uraian } & \multicolumn{2}{|c|}{ Perusahaan Peternakan Ayam Ras Petelur } \\
\hline & & $\begin{array}{ll}\text { UD. } & \text { Kakaskasen } \\
\text { Indah }\end{array}$ & $\begin{array}{ll}\mathrm{CV} . & \text { Nawanua } \\
\text { Farm } & \end{array}$ \\
\hline 1. & Tahun didirikan & 1987 & 1987 \\
\hline 2. & Status Peternakan & Milik Sendiri & Milik Sendiri \\
\hline 3. & Umur Peternak & 60 Tahun & 45 Tahun \\
\hline 4. & Pendidikan & Sarjana & Sarjana \\
\hline 5. & Pengalaman beternak & 26 Tahun & 26 Tahun \\
\hline 6. & Pekerjaan utama & Peternak & Peternak \\
\hline 7. & Pekerjaan sampingan & Wiraswasta & Wiraswasta \\
\hline 8. & Luas Areal Lahan & $4 \mathrm{Ha}$ & $2 \mathrm{Ha}$ \\
\hline \multirow[t]{4}{*}{9.} & Peralatan : & & \\
\hline & - Mesin giling & 2 unit & 2 unit \\
\hline & - Mesin diesel & - & 1 unit \\
\hline & Timbangan & 2 unit & 2 unit \\
\hline 10. & Jumlah ternak ayam petelur: & 60.000 & 21.000 \\
\hline 11. & Jenis kandang & Semi Permanen & Semi Permanen \\
\hline 12. & Jumlah Gudang & 3 unit & 2 unit \\
\hline
\end{tabular}

Hasil penelitian menunjukkan bahwa masing-masing peternak telah cukup berpengalaman dan mempunyai keahlian dalam pengelolaan perusahaan peternakan ayam ras petelur karena peternak memiliki pengalaman dalam bidang peternakan. Faktor yang mendorong peternak tetap berusaha dalam peternakan tersebut disebabkan karena manajer yang menangani usaha peternakan ayam ras petelur sudah dapat dikatakan menguasai usaha yang dilakukannya.

Peralatan yang dimiliki selain mesin giling juga mesin diesel yang diperlukan untuk penyediaan air dan listrik jika terjadi padam listrik. Penggunaan mesin pompa disebabkan oleh air yang digunakan berasal dari sumur yang berada dilokasi peternakan selain air yang bersumber dari perusahaan air minum, sedangkan kebutuhan penerangan menggunakan instalasi listrik. 
Areal peternakan masing-masing perusahaan tidak seluruhnya digunakan untuk bangunan perusahaan peternakan ayam ras petelur. Penggunaan tenaga kerja pada masing-masing usaha peternakan, menggunakan tenaga kerja dari luar keluarga yang sehari-harinya mendapat pengawasan dan bimbingan langsung dari manajer bahkan pemilik usaha peternakan. Aktivitas pekerjaan yang dilakukan ialah menggiling butiran bahan pakan, menyusun ransum, pemberian pakan dan air minum, membersihkan kandang dan peralatan, perawatan ternak dan membersihkan lingkungan kandang serta membantu dalam hal pemasaran produk baik telur, ayam afkir maupun feses (kotoran ternak) sebagai pupuk kandang.

Faktor bibit (DOC) umumnya diperoleh peternak pada perusahaan pembibitan yang ada di Pulau Jawa (Surabaya). Perusahaan UD Kakaskasen Indah menggunakan bibit (DOC) jenis strain Lohman/Platinum Lohman yang diproduksi oleh PT. Wonokoyo Jaya Kusuma dan jenis Isa Brown yang diproduksi PT Charoen Phokphan sebanyak 7.500 ekor untuk satu periode produksi (satu partai). Perusahaan CV. Nawanua Farm membeli bibit (DOC) jenis strain Isa Brown yang diproduksi oleh PT. Wonokoyo sebanyak 5.000 ekor untuk satu periode produksi. Pemilihan strain bibit dilakukan berdasarkan kemampuan berproduksi dari jenis ayam petelur. Agar perusahaan ayam ras petelur berlangsung secara baik, maka bibit (DOC) dipesan terlebih dahulu oleh peternak dengan maksud menjaga ketersediaan stok bibit untuk mengganti ayam petelur ketika memasuki masa afkir. Strategi peternak dalam usaha memperoleh harga bibit yang layak (harga dibawah standar), pembelian bibit dilakukan pada saat harga bibit turun yaitu pada masa berpuasa umat beragama muslim dan sebulan sesudah hari raya idul fitri.

Bibit ayam (DOC) yang sudah datang dimasukkan dalam kandang yang sudah dibersihkan, disanitasi, dan diberi pemanas dengan suhu $37^{\circ} \mathrm{C}$ sampai $38^{\circ} \mathrm{C}$. Perlakuan yang dilakukan memberikan air minum ditambahkan dengan larutan gula, hal ini dimaksudkan untuk mencegah stress pada bibit ayam. Vaksin diberikan setelah 3 hari dimaksudkan untuk mencegah parasit pada ayam yang datangnya dari kandang.

Hasil penelitian diperoleh data bahwa, kedua perusahaan peternakan ayam ras petelur dalam menyusun ransum yang diberikan pada ternak ayam ras petelur terdiri dari bahan pakan yaitu; kosentrat, jagung, dedak halus, dan tepung ikan. Hasil penelitian diperoleh bahwa, rata-rata jumlah komposisi bahan pakan yang diberikan pada kedua perusahaan yaitu konsentrat $25,87 \%$, jagung $28,51 \%$, dedak $28,09 \%$, dan tepung ikan 17,53\%. Berdasarkan komposisi tersebut nampak bahwa, perbandingan 
komposisi bahan pakan yang diberikan oleh peternak belum sesuai dengan apa yang dianjurkan oleh beberapa sumber antara lain Abidin (2004) dan Rasyaf (2001) menyatakan bahwa, komposisi bahan pakan untuk jagung 60,5\%, dedak halus $14 \%$, kosentrat 15,5\% dan tepung ikan 10\%. Menurut Abidin (2004) dan Rasyaf (2001) bahwa, komposisi jagung harus lebih banyak dari dedak dan konsentrat sebab kandungan kuning yang ada dalam jagung berfungsi untuk menambah kualitas kuning telur. Menurut peternak berdasarkan pengalaman mereka bahwa, komposisi bahan pakan yang diberikan untuk ayam ras petelur perlu disesuaikan dengan jenis bibit ternak ayam ras petelur karena masing-masing strain mempunyai pola konsumsi yang berbeda. Jenis bibit ternak ayam ras petelur yang dipelihara yaitu Strain Lohman/Platinum Lohman dan jenis Strain Isa Brown untuk perusahaan UD. Kakaskasen Indah sedangkan perusahaan CV. Nawanua Farm menggunakan jenis bibit ternak ayam ras petelur Stain Isa Brown.

Pemberian pakan yang dilakukan pada perusahaan UD. Kakaskasen Indah dan CV. Nawanua Farm sebanyak 2 kali pada pukul 08.00 dan pada pukul 13.00. Jumlah pakan oleh kedua perusahaan peternakan ayam ras petelur diberikan rata-rata 80,42 gram/ekor/hari, jumlah pakan yang diberikan tersebut sudah sesuai dengan anjuran yang harus diberikan pada ternak ayam ras petelur walaupun masih pada standar minimum yaitu 79,99-100 gram/ekor/hari. Menurut Rasyaf (2001), menyatakan bahwa umumnya ayam petelur tipe ringan mengkonsumsi ransum sangat sedikit walaupun sedang aktif berproduksi, konsumsi umumnya berkisar antara 80-100 gram/ekor/hari. Pemberian air minum diberikan secara ad libitum atau diberikan terus menerus tanpa batas yang sudah disiapkan melalui tempat minum ternak.

Hasil penelitian menunjukkan bahwa sistim perkandangan ayam ras petelur pada kedua perusahaan ayam ras petelur menggunakan sistem battery dengan susunan tiga tingkat yang bahannya terbuat dari bambu dan kawat. Adapun ukuran setiap kotak ialah $45 \mathrm{~cm}$ x $41 \mathrm{~cm}$ x $46 \mathrm{~cm}$ dan setiap kotak terdiri dari 2 ekor ayam.

Perusahaan UD. Kakaskasen Indah, konstruksi kandangnya semi permanan dimana lantai dan diding kandang terbuat dari beton, sedangkan atap dari seng agar supaya ternak ayam tidak akan terkena panas matahari secara langsung, arah kandang dari Barat ke Timur dan ada juga dari arah Utara - Selatan. Konstruksi kandang CV. Nawanua Farm rangka kandang dari bambu dan kayu dengan lantai beton. Arah kandang dari Timur ke Barat. Guna menjamin kehidupan ternak ayam yang hidupnya selalu terkurung dalam kandang, maka kandang tersebut harus memiliki perlengkapan 
kandang seperti: tempat makan, tempat minum, ember, sapu, sekop, dan perlengkapan kandang lainnya. Hasil penelitian menunjukkan tempat pakan yang digunakan untuk ayam ras petelur pada kedua usaha peternakan terbuat dari bambu yang diletakkan memanjang sepanjang kandang. UD Kakaskasen Indah memiliki tempat minum juga dari bambu yang diletakkan memanjang lebih tinggi dari tempat makan ternak, namun pada CV. Nawanua tempat minum terbuat dari plastik yang ditempatkan pada setiap kotak yang berisi ayam.

Tenaga kerja pada perusahaan ayam ras petelur baik perusahaan UD. Kakaskasen Indah dan perusahaan CV. Nawanua Farm umumnya berasal dari luar keluarga. Kegiatan yang dilaksanakan setiap hari yaitu menyusun ransum, pemberian ransum dan air minum, membersikan kandang dan peralatan, pengumpulan telur dan menampung kotoran (feces). Kegiatan tersebut dilaksanakan setiap hari mulai jam 07.00 pagi dan berakhir pukul 17.30 sore. Kegiatan-kegiatan tersebut dilaksanakan sesuai dengan tugas dan kerja masing-masing pekerja yang sudah ditugaskan oleh manajer.

Jumlah tenaga kerja pada perusahaan UD. Kakaskasen Indah sebanyak 27 orang dengan jumlah ternak ayam ras yang dipelihara sebanyak 60.000 ekor, sedangkan perusahaan CV. Nawanua Farm menggunakan tenaga kerja sebanyak 19 orang dengan jumlah ternak ayam ras petelur yang dipelihara sebanyak 21.000 ekor. Menurut Rasyaf (2001) menyatakan bahwa 1 orang tenaga kerja laki-laki dewasa mampu menangani 3500 ekor ayam ras petelur fase layer secara manual. Tenaga kerja yang digunakan pada kedua perusahaan ayam ras petelur, baik perusahaan UD. KI dan perusahaan UD. Lokon telah terjadi kelebihan tenaga jika dibandingkan dengan anjuran Rasyaf (2001). Apabila perusahaan UD. Kakaskasen Indah berjumlah 27 orang tenaga kerja seharusnya jumlah ternak yang ditangani sebanyak 94.500 ekor, sedangkan perusahaan CV. Nawanua Farm berjumlah 19 orang tenaga kerja seharusnya jumlah ternak yang ditangani sebanyak 66.500 ekor. Penggunaan tenaga kerja pada kedua perusahaan ayam ras petelur, baik perusahaan UD. Kakaskasen Indah dan perusahaan CV. Nawanua Farm tidak efisien.

Berdasarkan hasil penelitian terhadap pengalaman peternak dan pekerja yang ada, bahwa pada perusahaan ayam ras petelur, baik perusahaan CV. Nawanua Farm dan UD. Kakaskasen Indah ternak ayam ras petelur yang diusahakan selama ini belum pernah mengalami penyakit yang membawa kematian ternak yang mengakibatkan 
kerugian bagi peternak. Hal ini karena peternak selalu memperhatikan kesehatan ternak dengan pemberian vaksin yang teratur dan vitamin serta obat-obat pencegahan penyakit. Ternak yang mati biasanya pada saat ternak masih berumur DOC dan masa pra produksi, hal inipun akibat dari ternak mengalami stress ataupun pada saat penyesuaian lingkungan.

Hasil penelitian, diperoleh bahwa ayam mulai berproduksi pada umur 17 minggu dan diafkir pada umur 82 minggu. Hal ini dilakukan karena pada saat ternak berumur di atas 82 minggu, produksi telur sudah menurun hingga 49,67\% pada perusahaan CV. Nawanua Farm dan 51,74\% pada perusahaan UD. Kakaskasen Indah, sehingga jika dilakukan pemberian pakan terus menerus akan mengakibatkan kerugian. Puncak produksi bertelur dicapai pada umur 28 minggu dengan produksi mencapai 93,86\% pada perusahan CV. Nawanua Farm dan 93,04\% pada perusahan UD. Kakaskasen Indah terhitung mulai ternak tersebut bertelur, kemudian produksi telur mulai mengalami penurunan. Penurunan produksi dipengaruhi oleh umur ayam, biasanya sulit diatasi sehingga perlu peremajaan pengadaan bibit yang baru.

Produksi telur pada masing-masing perusahan setiap minggu berbeda, hal ini dipengaruhi skala usaha yang dimiliki. Perusahaan CV. Nawanua Farm memiliki populasi 21.000 ekor saat DOC tetapi pada saat berproduksi populasi sebanyak 19.934 ekor (20,04\% produk telur) hingga akhir produksi berjumlah 18.900 ekor $(46,67 \%$ produk telur) pada umur 82 minggu. Perusahaan UD. Kakaskasen Indah memiliki populasi 60.000 ekor saat DOC tetapi pada saat berproduksi populasi sebanyak 57.383 ekor $(21,20 \%$ produk telur) hingga akhir produksi berjumlah 56.068 ekor $(51,74 \%$ produk telur) pada umur 82 minggu.

Produksi telur pada kedua perusahaan ayam petelur ditinjau dari rata-rata produksi telur per minggu selama 82 minggu berproduksi diperoleh hasil bahwa, pada perusahaan CV. Nawanua Farm rata-rata sebanyak 91.590 butir/minggu, dari produksi tersebut tidak semunya utuh dipasarkan karena terdapat telur yang pecah (retak). Ratarata telur pecah (retak) sebanyak 1.114 butir/minggu. Pada perusahaan UD. Kakaskasen Indah rata-rata sebanyak 285.285 butir/minggu, dari produksi tersebut tidak semunya utuh dipasarkan karena terdapat telur yang pecah (retak). Rata-rata telur pecah (retak) sebanyak 3.893 butir/minggu. Telur yang pecah tersebut tetap dipasarkan melalui pasar lokal (khususnya kepada konsumen yang membuat kue maupun konsumen rumah tangga) dengan harga yang relatif lebih murah dari telur yang utuh atau baik. 
Berdasarkan hasil penelitian dapat diketahui bahwa tingkat mortalitas dari ternak ayam ras petelur pada kedua perusahaan baik CV. Nawanua Farm dan UD. Kakaskasen Indah terdapat perbedaan kuantitas karena skala usaha yang berbeda pula. Pada perusahaan CV. Nawanua Farm mortalitas DOC sampai umur 6 minggu sebesar 0,51\%/minggu. Sejak umur 7 minggu sampai mulai berproduksi pada umur 16 minggu mortalitas sebesar 0,21\%/minggu sedangkan sementara berproduksi sampai diafkir mortalitasnya sebesar 0,08\%/minggu. Perusahaan UD. Kakaskasen Indah mortalitas DOC sampai umur 6 minggu sebesar 0,32\%/minggu. Sejak umur 7 minggu sampai mulai berproduksi pada umum 16 minggu mortalitas sebesar 0,20\%/minggu sedangkan sementara berproduksi sampai diafkir mortalitasnya sebesar $0.04 \% /$ minggu. Menurut peternak dan pekerja di kandang, tingkat mortalitas tersebut bukan akibat dari suatu penyakit namun disebabkan karena pada ayam umur DOC mengalami penyesuaian lingkungan sedangkan pada periode pra produksi dan produksi disebabkan karena stress.

Pada kedua perusahaan ayam petelur baik perusahan CV. Nawanua Farm dan UD. Kakaskasen Indah, pemasaran produk ayam ras petelur yang dimaksud adalah pemasaran telur dan ayam afkir. Saluran pemasaran yang digunakan oleh kedua perusahaan ayam petelur baik perusahan CV. Nawanua Farm dan UD. Kakaskasen Indah dalam memasarkan telur dan ayam afkir meliputi tiga saluran yaitu: (1) dari peternak langsung kepada konsumen, dan (2) dari peternak ke pedagang pengumpul, dan (3) dari peternak ke pedagang pengecer. Hasil penelitian Sejati (2010) dan Wahyuningsih (2008) di pulau Jawa, pemasaran telur dan ayam afkir berlaku tiga saluran seperti halnya yang berlaku di Tomohon.

Adapun harga telur yang dipasarkan oleh kedua perusahaan ayam petelur baik perusahan CV. Nawanua Farm dan UD. Kakaskasen Indah tidak ada perbedaan signifikan yaitu rata-rata sebesar Rp. 1.200 per butir untuk telur utuh dan Rp. 900 per butir untuk telur retak, sedangkan untuk ayam afkir dijual setelah berumur 8 minggu dengan harga rata-rata Rp. 37.700 per ekor/minggu.

Saluran pemasaran untuk produk ayam afkir untuk setiap minggunya, langsung dipasarkan ke konsumen akhir, sedangkan untuk ayam afkir yang di panen pada saat berakhirnya produksi, pemasarannya ada yang langsung ke konsumen akhir dan melalui pedagang pengumpul/perantara yang sudah menjadi pelanggan tetap, baik pedagang yang ada di Kota Tomohon maupun di Kota Manado. Harga ayam afkir dijual dengan harga Rp. 37.700 s.d Rp.40.500 per ekor. 
Biaya produksi sebelum berproduksi ialah biaya bibit (DOC) 3,95\% untuk perusahaan CV. Nawanua Farm dan 4,26\% untuk perusahaan UD. Kakaskasen Indah kemudian biaya pakan sebesar 7,45\% untuk perusahaan CV. Nawanua Farm dan 8,08\% untuk perusahaan UD. Kakaskasen Indah sedangkan biaya tenaga kerja sebesar 4,47\% untuk perusahaan CV. Nawanua Farm dan 2,99\%\% untuk perusahaan UD. Kakaskasen Indah.

Hasil penelitian menunjukkan bahwa pada perusahaan CV. Nawanua Farm, biaya produksi sebelum berproduksi untuk biaya tetap sebesar $4,07 \%$ dan biaya tidak tetap sebesar $12,45 \%$, artinya biaya produksi sebelum berproduksi pada perusahaan CV. Nawanua Farm sebesar 16,52\% dari keseluruhan biaya produksi. Sedangkan pada perusahaan UD. Kakaskasen Indah, biaya produksi sebelum berproduksi untuk biaya tetap sebesar 4,33\% dan biaya tidak tetap sebesar $11,68 \%$, artinya biaya produksi sebelum berproduksi pada perusahaan UD. Kakaskasen Indah sebesar 16,02\% dari keseluruhan biaya produksi.

Biaya produksi pada saat berproduksi pada perusahaan CV. Nawanua Farm terbesar ialah biaya pakan $61,99 \%$ dan $68,58 \%$ untuk perusahaan UD. Kakaskasen Indah kemudian disusul dengan biaya tenaga kerja sebesar 18,31\% untuk perusahaan CV. Nawanua Farm dan 12,30\% untuk perusahaan UD. Kakaskasen Indah. Tabel 2 nampak bahwa pada perusahaan CV. Nawanua Farm, biaya produksi pada saat berproduksi untuk biaya tetap sebesar $0,60 \%$ dan biaya tidak tetap sebesar $82,88 \%$, artinya biaya produksi pada saat berproduksi untuk perusahaan CV. Nawanua Farm sebesar $83,48 \%$ dari keseluruhan biaya produksi. Sedangkan pada perusahaan UD. Kakaskasen Indah, biaya produksi pada saat berproduksi untuk biaya tetap sebesar $0,37 \%$ dan biaya tidak tetap sebesar $83,61 \%$, artinya biaya produksi pada saat berproduksi untuk perusahaan UD. Kakaskasen Indah sebesar 83,98\% dari keseluruhan biaya produksi.

Berdasarkan data hasil penelitian, masing-masing perusahaan ayam petelur baik perusahaan CV. Nawanua Farm dan UD. Kakaskasen Indah menunjukkan bahwa biaya terbesar dari keseluruhan biaya produksi ialah biaya pakan sebesar 69,44\% untuk perusahaan CV. Nawanua Farm dan 76,66\% untuk perusahaan UD. Kakaskasen Indah diikuti biaya tenaga kerja sebesar 22,78\% untuk perusahaan CV. Nawanua Farm dan $15,29 \%$ untuk perusahaan UD. Kakaskasen Indah. Hasil penelitian ini didukung pendapat dari beberapa hasil penelitian yang menyatakan bahwa, biaya produksi terbesar pada usaha ayam ras petelur ialah biaya pakan diikuti biaya tenaga kerja, yaitu 
biaya pakan berkisar antara $70 \%$ sampai $80 \%$ dan biaya tenaga kerja $10 \%$ sampai $20 \%$ dari keseluruhan biaya produksi dalam satu periode produksi (Abidin, 2004; Rasyaf, 2001; Sudaryani dan Santosa, 2000).

Hasil penelitian menunjukkan bahwa nilai Break Even Point (BEP unit), Break Even Point (BEP rupiah) dan Margin Of Safety (MOS) serta Return Of Investment (ROI) pada perusahaan ayam ras petelur di Tomohon dapat dijelaskan sebagai berikut : 1). Perusahaan Peternakan Ayam Ras Petelur CV. Nawanua Farm

Nilai Break Even Point pada perusahaan peternakan ayam ras petelur CV. Nawanua Farm berada pada nilai volume produksi 10.955,83 unit atau 10.956 ekor dengan tingkat keuntungan Rp. 209.297.896 per periode produksi. Hasil ini menunjukkan bahwa perusahaan peternakan ayam ras petelur CV. Nawanua Farm memperoleh tingkat keuntungan yang baik, artinya sudah melampaui titik impas. Hal ini dijelaskan oleh hasil analisis Margin Of Safety (MOS) sebesar 94,36\%, artinya apabila tingkat produksi mengalami penurunan sebesar 94,36\% maka usaha peternakan ayam ras petelur tersebut masih berada dalam kedudukan titik impas (tidak untung dan tidak rugi). Hal tersebut dapat diterangkan dengan nilai ROI yaitu, untuk mengetahui tingkat efisinsi dari modal yang telah dikeluarkan. Nilai ROI diperoleh sebesar 1,78. Artinya penggunaan modal (biaya produksi) pada perusahaan peternakan ayam ras petelur CV. Nawanua Farm di Tomohon sudah efisien atau memberikan tingkat keuntungan. Dengan demikian perusahaan peternakan ayam ras petelur CV. Nawanua Farm mengalami tingkat keuntungan yang signifikan pada tingkat keuntungan per ekor sebesar Rp. 249.869 per periode produksi.

\section{2). Perusahaan Peternakan Ayam Ras Petelur UD. Kakaskasen Indah}

Nilai titik impas perusahaan peternakan ayam ras petelur UD. Kakaskasen Indah berada pada nilai volume produksi $24.851,45$ unit atau 24.851 ekor dengan tingkat keuntungan Rp. 517.417.088 per periode produksi. Tabel 4 menunjukkan bahwa, perusahaan peternakan ayam ras petelur UD. Kakaskasen Indah memperoleh tingkat keuntungan yang baik, artinya sudah melampaui titik impas. Hal ini dijelaskan oleh hasil analisis Margin Of Safety (MOS) sebesar 96,38\%, artinya apabila tingkat produksi mengalami penurunan sebesar 96,38\% maka perusahaan peternakan ayam ras petelur UD. Kakaskasen Indah tersebut masih berada dalam kedudukan titik impas (tidak merugi). Hal tersebut dapat diterangkan dengan nilai ROI yaitu, untuk mengetahui tingkat efisinsi dari modal yang telah dikeluarkan. Nilai ROI diperoleh nilai 2,25. 
Artinya penggunaan modal (biaya produksi) pada perusahaan peternakan ayam ras petelur UD. Kakaskasen Indah di Tomohon sudah efisien atau memberikan tingkat keuntungan. Dengan demikian perusahaan peternakan ayam ras petelur UD. Kakaskasen Indah mengalami tingkat keuntungan yang signifikan pada tingkat keuntungan per ekor sebesar Rp. 292.054 per periode produksi.

\section{KESIMPULAN DAN SARAN}

\section{Kesimpulan}

Berdasarkan hasil penelitian dapat disimpulkan bahwa :

1. Masing-masing perusahaan peternakan ayam ras petelur CV. Nawanua Farm dan UD. Kakaskasen Indah di Kota Tomohon memberikan keuntungan yang maksiumum per periode produksi yang dibuktikan dengan nilai Margin Of Safety (MOS) serta Return Of Investment (ROI) yang diperoleh.

2. Nilai Break Even Point (BEP unit) dan Break Even Point (BEP rupiah) yang diperoleh pada masing-masing perusahaan peternakan ayam ras petelur $\mathrm{CV}$. Nawanua Farm dan UD. Kakaskasen Indah di Kota Tomohon berada pada volume produksi yang menguntungkan sebab sudah beroperasi diatas nilai titik impas.

\section{Saran}

Berdasarkan hasil penelitian dapat disarankan bahwa untuk meningkatkan keuntungan yang lebih besar pada perusahaan peternakan ayam ras petelur CV. Nawanua Farm dan UD. Kakaskasen Indah di Kota Tomohon perlu ditambah skala usaha (jumlah ternak ayam ras petelur) mengingat nilai BEP, nilai MOS serta nilai ROI membuktikan perusahaan tersebut masih dapat mendatangkan tingkat keuntungan yang lebih besar.

\section{DAFTAR PUSTAKA}

http://alfahchintya23.wordpress.com/2008/02/23/metode-penelitian-studi-kasus/. 2008. Metode Penelitan Studi Kasus.

Abidin, Z. 2004. Meningkatkan Produktivitas Ayam Ras Petelur. Agromedia Pustaka. Jakarta.

Rasyaf, 2001. Beternak Ayam Ras Petelur. Edisi Revisi. Penebar Swadaya. Jakarta.

Sejati, K. W. 2010. Analisis kelembagaan rantai pasok telur ayam ras peternakan rakyat di Jawa Barat. Analisis Kebijakan Pertanian . No. 2. Hal : 183-198. Bogor. 
Sudaryani T. dan H. Santosa. 2000. Pemeliharaan Ayam Ras Petelur di Kandang Baterai. Cetakan ke-4. Penebar Swadaya Jakarta.

Wahyuningsih, R. 2008. Analisis permintaan telur ayam di Jawa Timur. Agritek Vol. 16 NO. 11. Malang. 